\title{
Pengaruh Pemangkasan Tunas Lateral dan Bunga Terhadap Pertumbuhan dan Hasil Terung (Solanum melongena, L.).
}

\section{Rofinus Nahak Seran ${ }^{\mathrm{a}}$}

${ }^{a}$ Fakultas Pertanian, Universitas Timor, Kefamenanu, TTU - NTT, 85613, Indonesia.

\section{Article Info}

\section{Article history:}

Received 20 Desember 2015

Received in revised form 17 Januari 2016

Accepted 18 Maret 2016

\section{Keywords:}

Terung

Pemangkasan Bung

Pemangkasan Tunas Lateral

Solanum melongena, L

\begin{abstract}
Abstrak
Penelitian ini bertujuan untuk mengetahui pengaruh pemangkasan tunas lateral dan bunga terhadap pertumbuhan dan hasil terung. Penelitian mengunakan Rancangan Acak Kelompok (RAK) faktorial 3 x 3 yang diulang tiga kali. Faktor pertama adalah pemangkasan tunas lateral yang terdiri dari tiga aras yaitu pangkas satu tunas, pangkas dua tunas, pangkas tiga tunas. Pemangkasan bunga yang terdiri dari tiga aras yaitu pangkas satu bunga, pangkas dua bunga dan pangkas tiga bunga. Hasil penelitian menunjukkan interaksi antara pemangkasan tunas lateral dan pemangkasan bunga berpengaruh nyata terhadap diameter batang, diameter buah, berat per buah, berat buah per tanaman, berat buah per petak panen III dan total panen, berat segar berangkasan dan indeks panen. Pemangkasan satu tunas lateral memberikan hasil buah per petak yang lebih baik seberat 14,327 t/ha jika dibandingkan dengan pemangkasan dua atau tiga tunas lateral. Pemangkasan satu bunga memberikan hasil buah per petak yang lebih baik seberat 14,419 t/ha jika dibandingkan dengan pemangkasan dua atau tiga bunga. Pemangkasan satu tunas dan satu bunga yang dilakukan bersama menghasilkan buah setiap petak tertinggi yang mencapai 19,264 t/ha. @2016 dipublikasikan oleh Savana Cendana.
\end{abstract}

\section{Pendahuluan}

Terung merupakan jenis tumbuhan yang dikenal sebagai sayur-sayuran dan ditanam untuk dimanfaatkan sebagai bahan makanan. Akhir-akhir ini bisnis terung masih memberikan peluang pasar yang cukup baik terutama untuk memenuhi permintaan pasar dalam negeri (Liana, 2007).

Buah terung dikonsumsi oleh masyarakat dalam bentuk berbagai sayur atau lalapan karen mengandung gizi yang cukup tinggi dan komposisinya lengkap. Menurut Soetasad (2000) terung ungu termasuk salah satu sayuran buah yang banyak digemari oleh berbagai kalangan karena mengandung kalsium, protein, lemak, karbohidrat, vitamin A, vitamin B, vitamin C, fosfor dan zat besi.

Usaha yang dapat dilakukan untuk meningkatkan produksi tanaman terung selain dengan usaha ekstensifikasi, diversifikasi dan rehabilitasi juga dapat dilakukan melalui intensifikasi. Menurut Adisarwanto dan Wudianto (2002), ada beberapa tekhnologi yang terbukti mampu meningkatkan hasil panen, baik secara kualitas maupun kuantitas, salah satu usaha tersebut adalah pemangkasan. Menurut Cahyono (1996), pemangkasan adalah usaha untuk menghilangkan tunas, bunga dan daun tanaman yang tidak diperlukan. Salah satu fungsi pemangkasan adalah untuk mengatur penerimaaan cahaya matahari agar proses fotosintesis dapat berjalan lebih baik sehingga dapat meningkatkan pertumbuhan generatifnya yakni pembentukan bunga, buah. Selanjutnya dinyatakan bahwa pemangkasan bunga awal berfungsi untuk meransang cabang-cabang produktif. Sunaryono (1984) menyatakan tanaman yang berdaun rimbun tidak akan berbuah lebat, hingga produksinya rendah, dengan pemangkasan diharapkan massa daun berkurang, sehingga tanaman akan berbuah banyak dan produksinya pun meningkat.

Ada dua jenis pemangkasan pada tanaman terung yaitu pemangkasan tunas dan pemangkasan bunga. Tunas yang tumbuh diketiak daun pertama sampai tunas yang di bawah bunga yang kedua harus dibuang. Pemangkasan bunga dilakukan pada bunga pertama. Pemangkasan dilakukan sedini mungkin, sebelum tunas atau bunga tumbuh besar (Pracaya, 2002).

Wochjar (1984) cit. Gernawi (1996) menyatakan pada dasarnya pemangkasan bertujuan mengatur pertumbuhan vegetatif ke arah generatif Dengan kata lain mengatur tanaman agar hanya menghasilkan cabang-cabang yang produktif. Kemudian Soeseno (1984) cit. Gernawi (1996) menyatakan bahwa apabila pemangkasan dilakukan maka fotosintat akan digunakan untuk memperbesar buah. Penelitian yang dilakukan oleh Sumiati (1987) menunjukkan bahwa pemangkasan tunas lateral tanaman tomat meningkatkan bobot per buah dan bobot buah per tanaman.

Bunga awal pada tanaman terung jika tidak dipangkas akan menghamba pertumbuhan pada cabang-cabang produktif baru sehinga bunga yang tumbuh tidak banyak untuk dapat menghasilkan buah terung (Soetasad dan Muryanti, 2000). Menurut Susanto dan Pribadi (2004), praktek penjarangan bunga akan mengurangi persaingan antar organ generatif sehingga dapat memperbaiki kualitas buah.

Pemangkasan yang tepat dapat meningkatkan hasil sebesar 35\% lebih tingg dibanding tanaman yang tidak dipangkas (Nakasone, 1954 cit. Muhammad et al. 2000). Permasalahannya adalah belum diketahui pengaruh pemangkasan pada terung sehingga penelitian ini bertujuan untuk mengetahui pengaruh pemangkasan tunas lateral dan bunga terhadap pertumbuhan dan hasil terung.

\section{Metode}

2.1 Waktu dan Tempat

Penelitian dilaksanakan bulan Juli sampai Oktober 2015 di kebun masyarakat, KM 5, Kelurahan Maubeli, Kecamatan Kota Kefamenanu, Kabupaten TTU.

\subsection{Rancangan Percobaan}

Rancangan yang digunakan dalam penelitian ini adalah Rancangan Acak Kelompok $(\mathrm{RAK})$ pola faktorial $3 \times 3$ yang diulang sebanyak tiga kali. Fakto pertama adalah pemangkasan tunas lateral $(\mathrm{T})$ yang terdiri dari tiga aras yaitu pangkas satu tunas $\left(\mathrm{t}_{1}\right)$, pangkas dua tunas $\left(\mathrm{t}_{2}\right)$, pangkas tiga tunas $\left(\mathrm{t}_{3}\right)$. Faktor kedua adalah pemangkas bunga (B) yang terdiri dari tiga aras yaitu pangkas satu bunga $\left(b_{1}\right)$, pangkas dua bunga $\left(b_{2}\right)$ dan pangkas tiga bunga $\left(b_{3}\right)$. Kombinasi perlakuannya adalah $t_{1} b_{1}, t_{1} b_{2}, t_{1} b_{3}, t_{2} b_{1}, t_{2} b_{2}, t_{2} b_{3}, t_{3} b_{1}, t_{3} b_{2}$ dan $t_{3} b_{3}$.

\subsection{Pelaksanaan Penelitian}

a. Persiapan Benih

Benih terung yang ditanam adalah terung varietas Mustang yang diperoleh dari toko sarana produksi pertanian yang menyediakannya sesuai dengan kebutuhan.

b. Pengolahan Tanah

Pengolahan tanah dilakukan dengan cara tanah dicangkul dan dibiarkan selama satu minggu. Selanjutnya dibuat bedengan dengan panjang 4,2 m, leba $3,5 \mathrm{~m}$ dan tinggi $30 \mathrm{~cm}$, sebanyak sembilanbuah pada masing-masing blok yang terdiri tiga blok. Jarak antar petak $0,5 \mathrm{~m}$ dan jarak antar blok $1 \mathrm{~m}$, jumlah petak keseluruhan adalah 27 petak dengan luas lahan 547,5 $\mathrm{m}^{2}$ (37,5 m x 14,6 m).Pembuatan lubang tanam dilakukan setelah bedengan selesai dibentuk dengan jarak antar lubang dalam satu baris $60 \mathrm{~cm}$ dan jarak antar baris $70 \mathrm{~cm}$ (70 $\mathrm{cm}$ x $60 \mathrm{~cm}$ ), diameter lubang tanam $20 \mathrm{~cm}$ dengan kedalaman $15 \mathrm{~cm}$. Pada setiap blok, petak, tanaman sampel dan tanaman korban diberikan label menggunakan tiang bambu dan seng.

c. Pembibitan

Sebelum ditanam, benih disemaikan di tempat persemaian yang telah dipersiapkan di atas bedengan yang berukuran panjang $2 \mathrm{~m}$, lebar dan tinggi 1,5 $\mathrm{cm}$ dan diberi atap dengan ukuran tinggi bagian belakang $\pm 90 \mathrm{~cm}$ dan bagian depan $\pm 125 \mathrm{~cm}$, serta arah atap menghadap ke timur. Setelah 14 hari setelah semai, kecambah siap dipindah ke dalam polibag semai ukuran diameter $10 \mathrm{~cm}$ yang diberi media campuran tanah dan pupuk kandang dengan perbandingan 2:1 Penyiraman menggunakan hand sprayer dua kali sehari pada pagi dan sore hari. Bibit yang disiapkan sebanyak 1.040 tanaman (kebutuhan 945 tanaman dan 95 bibit cadangan).Siapkan polybag $10 \times 20 \mathrm{~cm}$, dan dilubangi kecil-kecil sekitar 2 4 lubang pada bagian sisi-sisinya. Masukkan media tanam yang berupa campuran tanah, pupuk kandang sapi dan pupuk kandang kambing, polybag yang telah berisi bibit, diletakkan dibawah para-para yang diberi atap daun kelapa, agar tidak langsung tersengat terik matahari.

d. Penanaman

Penanaman dilakukan setelah bibit terung berumur 26 hari dan telah memiliki 4-5 helai daun. Tiap lubang tanam ditanam satu bibit terung yang dilakukan pada sore hari. Bibit ditanam dengan membenamkan bersama media kedalam lubang tanam sebatas leher akar. Setelah melakukan penanaman, bibit disiram dengan air secukupnya. Jumlah tanaman dalam setiap petak adalah 35 tanaman dengan jumlah keseluruhan 945 tanaman.

e. Pemangkasan

Tanaman yang dipangkas disesuaikan dengan perlakuan yaitu pada pada sembilan petak dilakukan pemangkasan terhadap satu tunas, pada sembilan petak dilakukan pemangkasan terhadap dua tunas dan pada sembilan petak dilakukan pemangkasan tiga tunas. Demikian pula pemangkasan bunga awal. Pemangkasan mulai dilakukan pada saat tanaman berumur 45 HST. Tunas dan bunga terung dipangkas dengan cara digunting pada tangkainya dengan menggunakan gunting yang bersih.

f. Pemeliharaan

Pemeliharaan meliputi penyiraman, penyulaman, pembumbunan, penyiangan serta pengendalian hama dan penyakit tanaman. Penyiraman dilakukan menggunakan kaleng dengan volume air 1 liter untuk setiap tanaman pada pagi dan sore hari. Penyulaman dilakukan pada saat tanaman berumur 10 HST. Penyulaman dilakukan dengan cara mengganti bibit yang mati atau rusak dengan bibit cadangan yang telah disiapkan. Pembumbunan dilakukan dengan cara menimbun tanah di sekitar pangkal batang. Penyiangan terhadap gulma dilakukan dengan mencabutnya dan bila perlu dibantu dengan alat pencungkil, 
namun dilakukan hati-hati agar jangan sampai akar tanaman terganggu. Selama penelitian, tanaman tidak mengalami gangguan hama dan penyakit tanaman

g. Panen

Panen dilakukan mulai tanaman berumur 70 HST, caranya buah terung dipotong pada tangkainya dengan menggunakan pisau yang tajam dan bersih. Buah yang siap panen adalah buah yang jika ditekan akan terasa lunak dan belum mengeras. Panen dilakukan tiga kali dengan interval waktu satu minggu. Panen ketiga dilakukan secara rampasan yaitu memetik buah terung secara keseluruhan.

\subsection{Parameter Pengamatan}

a. Tinggi Tanaman $(\mathrm{cm})$

Tinggi tanaman diukur dari pangkal batang sampai ujung daun paling tinggi, pengukuran menggunakan pengaris centimeter. Pengukuran dilakukan pada lima tanaman sampel saat berumur 14 HST, 35 HST dan 56 HST.

b. Diameter Batang $(\mathrm{cm})$

Pengukuran diameter batang dilakukan dengan menggunakan jangka sorong dengan cara menjepit pada bagian batang ( $1 \mathrm{~cm}$ di atas pangkal batang) dari lima tanaman sampel pada setiap petak. Pengukuran dilakukan pada saat tanaman berumur 14 HST, 35 HST dan 56 HST.

c. Luas Daun $\left(\mathrm{cm}^{2}\right)$

Luas daun diukur pada saat tanaman berumur 56 HST. Pengukuran luas daun dilakukan menggunakan metode fotografi dengan cara mengambil semua daun pada tiga tanaman korban pada tiap petak, kemudian daun dipotret menggunakan kamera digital. Luas area daun kemudian dihitung menggunakan program ImageJ versi 1.410 .

d. Panjang Buah $(\mathrm{cm})$

Panjang buah diukur dengan menggunakan mistar dari pangkal hingga ujung buah. Buah yang diukur adalah semua buah yang dipanen dari lima tanaman sampel pada setiap petak kemudian dirata-ratakan. Pengukuran dilakukan setiap kali panen kemudian dirata-ratakan untuk memperoleh ukuran panjang buah.

e. Diameter Buah (mm)

Pengukuran diameter buah dilakukan dengan menggunakan jangka sorong dengan cara menjepit pada bagian buah yang terbesar. Buah yang diukur adalah semua buah yang dipanen dari lima tanaman sampel pada setiap petak kemudian dirata-ratakan.

\section{f. Berat Per Buah $(\mathrm{g})$}

Pengukuran berat per buah dilakukan dengan cara menimbang setiap buah menggunakan timbangan. Buah yang diukur adalah semua buah yang dipanen dari lima tanaman sampel pada setiap petak kemudian dirata-ratakan.

g. Jumlah Buah Per Tanaman

Buah yang dipanen dari lima tanaman sampel dihitung kemudian dirataratakan. Perhitungan dilakukan setiap kali panen kemudian dijumlahkan untuk mendapatkan jumlah buah per tanaman.

h. Berat Buah Per Tanaman (g)

Berat buah per tanaman diukur dengan cara menimbang buah menggunakan timbangan analitik. Buah yang ditimbang adalah semua buah yang dipanen dari lima tanaman sampel pada setiap petak kemudian dirata-ratakan dengan cara berat total dibagi dengan jumlah tanaman sampel. Pengukuran dilakukan setiap kali panen kemudian dijumlahkan untuk memperoleh ukuran berat buah per tanaman.

\section{i. Jumlah Buah Per Petak}

Buah yang dipanen dari semua tanaman setiap petak dihitung. Perhitungan dilakukan setiap kali panen kemudian dijumlahkan untuk mendapatkan jumlah buah per petak total panen. Hasil perhitungan dikonversi untuk luas lahan satu hektar.

j. Berat Buah Per Petak (t/ha)

Berat buah per petak diukur dengan cara menimbang buah menggunakan timbangan gantung. Buah yang ditimbang adalah semua buah yang dipanen dari setiap petak. Pengukuran dilakukan setiap kali panen kemudian dijumlahkan untuk memperoleh ukuran berat buah per petak total panen kemudian dikonversi ke t/ha.

k. Berat Segar Berangkasan (t/ha)

Berat segar berangkasan diukur dengan cara menimbang berangkasan semua tanaman dalam setiap petak yang telah dipanen kemudian dikonversikan ke satuan t/ha. Pengukuran menggunakan timbangan duduk.

1. Berat Kering Berangkasan(t/ha)

Berat kering berangkasan diukur dengan cara menimbang berangkasan semua tanaman dalam setiap petak yang telah dipanen dan dijemur selama satu minggu kemudian dikonversikan ke satuan t/ha. Pengukuran menggunakan timbangan duduk.

m. Indeks Panen (\%)

Indeks panen dihitung dengan cara membandingkan berat bagian tanaman yang bernilai ekonomis dengan berat bagian seluruh tanaman kemudian dikonversikan ke satuan \%. Indeks panen dihitung dengan rumus:

$$
\mathrm{IP}=\frac{\mathrm{A}}{\mathrm{A}+\mathrm{B}} \mathrm{X} 100 \%
$$

Keterangan

$$
\text { IP : Indeks Panen (\%) }
$$

A $\quad$ : Berat Buah Per Petak (t/ha)

B : Berat Segar Brangkasan $(\mathrm{t} / \mathrm{ha})$
2.5 Analisis Data

Data hasil pengamatan kemudian dianalisis dengan menggunakan sidik ragam (Anova) Rancangan Acak Kelompok (RAK). Rata-rata perlakuan selanjutnya diuji lanjut dengan menggunakan Duncan Multiple Range Test (DMRT) dengan tingkat signifikasi 5\% sesuai petunjuk Gomez dan Gomez, (1995). Analisis data menggunakan program SAS 9.1.

\section{Hasil dan Pembahasan}

\subsection{Tinggi Tanaman}

Tanaman terus bertambah tinggi sejak awal hingga pengukuran terakhir. Hasil sidik ragam (Anova) menunjukkan tidak terjadi interaksi antara pemangkasan tunas lateral dan bunga terhadap tinggi tanaman 56 HST.

Pemangkasan bunga tidak berpengaruh nyata terhadap tinggi tanaman 56 HST tetapi data Tabel 1. menunjukkan bahwa tanaman yang tiga bunganya dipangkas cenderung lebih tinggi sedangkan tanaman yang satu bunganya dipangkas paling pendek. Pemangkasan tunas lateral juga tidak berpengaruh nyata terhadap tinggi tanaman 56 HST tetapi tanaman yang satu tunasnya dipangkas cenderung lebih tinggi sedangkan tanaman yang dua tunasnya dipangkas paling pendek.

\begin{tabular}{|c|c|c|c|c|c|}
\hline \multirow{2}{*}{$\begin{array}{c}\text { Waktu } \\
\text { Pengamatan }\end{array}$} & \multirow{2}{*}{$\begin{array}{c}\text { Pangkas } \\
\text { Bunga }\end{array}$} & \multicolumn{3}{|c|}{ Pemangkasan Tunas Lateral } & \multirow{2}{*}{ Rerata } \\
\hline & & 1 Tunas & 2 Tunas & 3 Tunas & \\
\hline \multirow{4}{*}{14 HST } & 1 Bunga & 15,7 & 15,1 & 15,0 & 15,3 \\
\hline & 2 Bunga & 15,1 & 15,2 & 15,1 & 15,1 \\
\hline & 3 Bunga & 15,1 & 15,3 & 15,6 & 15,3 \\
\hline & Rerata & 15,3 & 15,2 & 15,2 & \\
\hline \multirow{4}{*}{$35 \mathrm{HST}$} & 1 Bunga & 46,9 & 50,0 & 46,1 & 47,7 \\
\hline & 2 Bunga & 49,1 & 47,2 & 49,1 & 48,5 \\
\hline & 3 Bunga & 50,9 & 44,7 & 31,2 & 42,2 \\
\hline & Rerata & 49,0 & 47,3 & 42,1 & \\
\hline \multirow{4}{*}{56 HST } & 1 Bunga & 48,7 & 51,0 & 48,2 & $49,3 \mathrm{a}$ \\
\hline & 2 Bunga & 50,5 & 48,3 & 50,4 & $49,7 \mathrm{a}$ \\
\hline & 3 Bunga & 52,8 & 47,0 & 50,4 & $50,0 \mathrm{a}$ \\
\hline & Rerata & $50,6 \mathrm{a}$ & $48,8 \mathrm{a}$ & $49,6 \mathrm{a}$ & $(-)$ \\
\hline Keterangan & $\begin{array}{l}\text { Angka pad } \\
\text { tidak berbe } \\
\text { interaksi an }\end{array}$ & $\begin{array}{l}\text { dan kolc } \\
\text { ata menu } \\
\text { tor }\end{array}$ & ing diikut & gan hur & $\begin{array}{l}\text { ng sama } \\
\mathrm{k} \text { terjadi }\end{array}$ \\
\hline
\end{tabular}

\section{Tabel 1. Tinggi Tanaman (cm)}

3.2 Diameter Batang

Hasil sidik ragam (Anova) menunjukkan terjadi interaksi antara pemangkasan tunas lateral dan bunga terhadap diameter batang 56 HST dimana batang tanaman yang satu tunas dan dua bunganya dipangkas berdiameter paling besar yang berbeda nyata dengan diameter batang tanaman yang diberikan kombinasi perlakuan lainnya kecuali diameter batang tanaman yang satu tunas dan satu bunganya dipangkas dan juga diameter batang tanaman yang dua tunas dan satu bunganya dipangkas.

\begin{tabular}{|c|c|c|c|c|c|}
\hline \multirow{2}{*}{$\begin{array}{c}\text { Waktu } \\
\text { Pengamatan }\end{array}$} & \multirow{2}{*}{$\begin{array}{c}\text { Pangkas } \\
\text { Bunga }\end{array}$} & \multicolumn{3}{|c|}{ Pemangkasan Tunas Lateral } & \multirow{2}{*}{ Rerata } \\
\hline & & 1 Tunas & 2 Tunas & 3 Tunas & \\
\hline \multirow{4}{*}{14 HST } & 1 Bunga & 0,2 & 0,2 & 0,1 & 0,2 \\
\hline & 2 Bunga & 0,2 & 0,2 & 0,2 & 0,2 \\
\hline & 3 Bunga & 0,2 & 0,2 & 0,2 & 0,2 \\
\hline & Rerata & 0,2 & 0,2 & 0,2 & \\
\hline \multirow{4}{*}{35 HST } & 1 Bunga & 1,2 & 1,2 & 1,1 & 1,2 \\
\hline & 2 Bunga & 1,2 & 1,2 & 1,2 & 1,2 \\
\hline & 3 Bunga & 1,1 & 1,0 & 1,0 & 1,0 \\
\hline & Rerata & 1,2 & 1,1 & 1,1 & \\
\hline \multirow{4}{*}{$56 \mathrm{HST}$} & 1 Bunga & $1,5 \mathrm{ab}$ & $1,5 \mathrm{ab}$ & $1,4 \mathrm{bc}$ & $1,5 \mathrm{a}$ \\
\hline & 2 Bunga & $1,7 \mathrm{a}$ & $1,4 \mathrm{bc}$ & $1,2 \mathrm{~d}$ & $1,4 \mathrm{a}$ \\
\hline & 3 Bunga & $1,2 \mathrm{~cd}$ & $1,2 \mathrm{~d}$ & $1,1 \mathrm{~d}$ & $1,2 \mathrm{~b}$ \\
\hline & Rerata & $1,5 \mathrm{a}$ & $1,4 \mathrm{~b}$ & $1,2 \mathrm{c}$ & $(+)$ \\
\hline Keterangan : & $\begin{array}{l}\text { Angka pad } \\
\text { tidak berbe } \\
\text { antar fakto }\end{array}$ & dan kc & g diiku & $\begin{array}{l}\text { an huru } \\
+): T e\end{array}$ & \\
\hline
\end{tabular}

Tabel 2. Diameter Batang $(\mathrm{cm})$

Pemangkasan bunga berpengaruh nyata terhadap diameter batang 56 HST dimana batang tanaman yang satu bunganya dipangkas paling besar dan berbeda nyata dengan batang tanaman yang tiga bunganya dipangkas tetapi tidak berbeda nyata dengan diameter batang tanaman yang dua bunganya dipangkas. Pemangkasan tunas lateral juga berpengaruh nyata terhadap diameter batang 56 HST dimana batang tanaman yang satu tunasnya dipangkas paling besar dan berbeda nyata dengan batang tanaman yang dua tunasnya dipangkas maupun diameter batang tanaman yang tiga bunganya dipangkas.

\subsection{Luas Daun}

Hasil sidik ragam (Anova) menunjukkan tidak terjadi interaksi antara pemangkasan tunas lateral dan bunga terhadap luas daun.

Pemangkasan bunga tidak berpengaruh nyata terhadap luas daun tetapi data Tabel 3. menunjukkan bahwa permukaan daun tanaman yang dua bunganya dipangkas cenderung lebih luas sedangkan permukaan daun tanaman yang tiga 
bunganya dipangkas paling sempit. Pemangkasan tunas lateral tidak berpengaruh nyata terhadap luas daun tetapi permukaan daun tanaman yang dua tunasnya dipangkas cenderung lebih luas sedangkan permukaan daun tanaman yang tiga tunasnya dipangkas paling sempit.

Tabel 3. Luas Daun $\left(\mathrm{cm}^{2}\right)$

\begin{tabular}{|c|c|c|c|c|}
\hline \multirow{2}{*}{$\begin{array}{c}\text { Pemangkasan } \\
\text { Bunga }\end{array}$} & \multicolumn{3}{|c|}{ Pemangkasan Tunas Lateral } & \multirow{2}{*}{ Rerata } \\
\hline & 1 Tunas & 2 Tunas & 3 Tunas & \\
\hline 1 Bunga & 990 & 939 & 903 & $944 \mathrm{a}$ \\
\hline 2 Bunga & 1.041 & 1.260 & 864 & $1.055 \mathrm{a}$ \\
\hline 3 Bunga & 966 & 849 & 708 & $841 \mathrm{a}$ \\
\hline Rerata & $999 \mathrm{a}$ & $1016 \mathrm{a}$ & $825 \mathrm{a}$ & $(-)$ \\
\hline Keterangan : & $\begin{array}{l}\text { Angka pada b } \\
\text { tidak berbeda } \\
\text { interaksi antar }\end{array}$ & lom yan & $\begin{array}{l}\text { dengan } \\
5 \% \text {. ( }\end{array}$ & $\begin{array}{l}\text { ing sama } \\
\text { k terjadi }\end{array}$ \\
\hline
\end{tabular}

\subsection{Panjang Buah}

Hasil sidik ragam (Anova) menunjukkan tidak terjadi interaksi antara pemangkasan tunas lateral dan bunga terhadap panjang buah.

Pemangkasan bunga tidak berpengaruh nyata terhadap panjang buah tetapi data Tabel 4 . menunjukkan bahwa buah tanaman yang satu bunganya dipangkas cenderung lebih panjang sedangkan buah tanaman yang tiga bunganya dipangkas paling pendek. Pemangkasan tunas lateral juga tidak berpengaruh nyata terhadap panjang buah tetapi buah tanaman yang satu tunasnya dipangkas cenderung lebih panjang sedangkan buah tanaman yang tiga tunasnya dipangkas paling pendek.

Tabel 4. Panjang Buah $(\mathrm{cm})$

\begin{tabular}{ccccc}
\hline Pemangkasan & \multicolumn{2}{c}{ Pemangkasan Tunas Lateral } & \multirow{2}{*}{ Rerata } \\
\cline { 2 - 4 } Bunga & 1 Tunas & 2 Tunas & 3 Tunas & \\
\hline 1 Bunga & 22,6 & 21,6 & 19,7 & $21,3 \mathrm{a}$ \\
2 Bunga & 20,0 & 21,2 & 20,7 & $20,6 \mathrm{a}$ \\
3 Bunga & 20,5 & 19,3 & 12,8 & $17,5 \mathrm{a}$ \\
\hline Rerata & $21,0 \mathrm{a}$ & $20,7 \mathrm{a}$ & $17,7 \mathrm{a}$ & $(-)$ \\
\hline Keterangan : & Angka pada baris dan kolom yang diikuti dengan huruf yang sama \\
& tidak berbeda nyata menurut uji DMRT $\alpha 5 \% .(-)$ : Tidak terjadi \\
& interaksi antar faktor
\end{tabular}

\subsection{Diameter Buah}

Hasil sidik ragam (Anova) menunjukkan terjadi interaksi antara pemangkasan tunas lateral dan bunga terhadap diameter buah dimana diameter buah dari tanaman yang tiga tunas dan satu bunganya dipangkas paling besar sedangkan diameter buah tanaman yang satu tunas dan satu bunganya dipangkas paling kecil.

Pemangkasan bunga tidak berpengaruh nyata terhadap diameter buah tetapi data Tabel 5. menunjukkan bahwa buah tanaman yang tiga bunganya dipangkas cenderung lebih besar sedangkan buah tanaman yang dua bunganya dipangkas paling kecil. Pemangkasan tunas berpengaruh nyata terhadap diameter buah dimana buah tanaman yang tiga tunasnya dipangkas paling besar dan berbeda nyata dengan diameter buah tanaman yang dua tunasnya dipangkas maupun dengan diameter buah tanaman yang satu tunasnya dipangkas.

Tabel 5. Diameter Buah (mm)

\begin{tabular}{cllll}
\hline Pemangkasan & \multicolumn{2}{c}{ Pemangkasan Tunas Lateral } & \multirow{2}{*}{ Rerata } \\
\cline { 2 - 4 } Bunga & 1 Tunas & 2 Tunas & 3 Tunas & \\
\hline 1 Bunga & $4,04 \mathrm{~d}$ & $4,25 \mathrm{abc}$ & $4,40 \mathrm{a}$ & $4,23 \mathrm{a}$ \\
2 Bunga & $4,14 \mathrm{~cd}$ & $4,06 \mathrm{~d}$ & $4,36 \mathrm{ab}$ & $4,19 \mathrm{a}$ \\
3 Bunga & $4,30 \mathrm{abc}$ & $4,20 \mathrm{bcd}$ & $4,25 \mathrm{abc}$ & $4,25 \mathrm{a}$ \\
\hline Rerata & $4,16 \mathrm{~b}$ & $4,17 \mathrm{~b}$ & $4,34 \mathrm{a}$ & $(+)$ \\
\hline Keterangan : & Angka pada baris dan kolom yang diikuti dengan huruf yang sama \\
& tidak berbeda nyata menurut uji DMRT $\alpha 5 \%$. (+ ) : Terjadi interaksi \\
& antar faktor
\end{tabular}

\subsection{Berat Per Buah}

Hasil sidik ragam (Anova) menunjukkan terjadi interaksi antara pemangkasan tunas lateral dan bunga terhadap berat per buah dimana buah tanaman yang satu tunas dan satu bunganya dipangkas paling berat dan berbeda nyata dengan berat buah tanaman yang diberikan kombinasi perlakuan yang lainnya kecuali berat buah tanaman yang satu tunas dan dua bunganya dipangkas.

Tabel 6. Berat Per Buah (g)

\begin{tabular}{ccccc}
\hline Pemangkasan & \multicolumn{2}{c}{ Pemangkasan Tunas Lateral } & \multirow{2}{*}{ Rerata } \\
\cline { 2 - 4 } Bunga & 1 Tunas & 2 Tunas & 3 Tunas & \\
\hline 1 Bunga & $60,7 \mathrm{a}$ & $37,8 \mathrm{~b}$ & $30,4 \mathrm{~b}$ & $43,0 \mathrm{a}$ \\
2 Bunga & $54,0 \mathrm{a}$ & $41,0 \mathrm{~b}$ & $36,1 \mathrm{~b}$ & $43,7 \mathrm{a}$ \\
3 Bunga & $36,5 \mathrm{~b}$ & $36,3 \mathrm{~b}$ & $33,7 \mathrm{~b}$ & $35,5 \mathrm{~b}$ \\
\hline Rerata & $50,4 \mathrm{a}$ & $38,3 \mathrm{~b}$ & $33,4 \mathrm{~b}$ & $(+)$ \\
\hline Keterangan : & Angka pada baris dan kolom yang diikuti dengan huruf yang sama \\
& tidak berbeda nyata menurut uji DMRT $\alpha 5 \% .(+)$ : Terjadi interaksi \\
& antar faktor
\end{tabular}

Pemangkasan bunga berpengaruh nyata terhadap berat per buah dimana buah tanaman yang dua bunganya dipangkas paling berat dan berbeda nyata dengan berat buah tanaman yang tiga bunganya dipangkas tetapi tidak berbeda nyata dengan berat buah tanaman yang satu bunganya dipangkas. Pemangkasan tunas juga berpengaruh nyata terhadap berat per buah dimana buah tanaman yang satu tunasnya dipangkas paling berat dan berbeda nyata dengan berat buah tanaman yang dua tunasnya dipangkas maupun dengan berat buah tanaman yang tiga tunasnya dipangkas.

\subsection{Jumlah Buah Per Tanaman}

Hasil sidik ragam (Anova) menunjukkan tidak terjadi interaksi antara pemangkasan tunas lateral dan bunga terhadap jumlah buah per tanaman.

Pemangkasan bunga tidak berpengaruh nyata terhadap jumlah buah per tanaman tetapi data Tabel 7. menunjukkan bahwa buah setiap tanaman yang satu bunganya dipangkas cenderung lebih banyak sedangkan buah setiap tanaman yang tiga bunganya dipangkas paling sedikit. Pemangkasan tunas berpengaruh nyata terhadap jumlah buah per tanaman dimana buah setiap tanaman yang tiga tunasnya dipangkas paling banyak dan berbeda nyata dengan jumlah buah tanaman yang satu tunasnya dipangkas tetapi tidak berbeda nyata dengan jumlah buah tanaman yang dua tunasnya dipangkas.

Tabel 7. Jumlah Buah Per Tanaman

\begin{tabular}{ccccc}
\hline Pemangkasan & \multicolumn{3}{c}{ Pemangkasan Tunas Lateral } & \multirow{2}{*}{ Rerata } \\
\cline { 2 - 4 } Bunga & 1 Tunas & 2 Tunas & 3 Tunas & \\
\hline 1 Bunga & 13,1 & 14,1 & 15,5 & $14,3 \mathrm{a}$ \\
2 Bunga & 11,0 & 13,9 & 15,3 & $13,4 \mathrm{a}$ \\
3 Bunga & 12,9 & 12,5 & 13,3 & $12,9 \mathrm{a}$ \\
\hline Rerata & $12,4 \mathrm{~b}$ & $13,5 \mathrm{ab}$ & $14,7 \mathrm{a}$ & $(-)$ \\
\hline Keterangan : & \multicolumn{3}{l}{ Angka pada baris dan kolom yang diikuti dengan huruf yang sama } \\
& tidak berbeda nyata menurut uji DMRT $05 \%$. ( - ) : Tidak terjadi \\
& interaksi antar faktor
\end{tabular}

\subsection{Berat Buah Per Tanaman}

Hasil sidik ragam (Anova) menunjukkan terjadi interaksi antara pemangkasan tunas lateral dan bunga terhadap berat buah per tanaman dimana buah setiap tanaman yang satu tunas dan satu bunganya dipangkas paling berat dan berbeda nyata dengan berat buah setiap tanaman yang diberikan kombinasi perlakuan lainnya.

Pemangkasan bunga berpengaruh nyata terhadap berat buah per tanaman dimana buah setiap tanaman yang satu bunganya dipangkas paling berat dan berbeda nyata dengan berat buah setiap tanaman yang tiga bunganya dipangkas tetapi tidak berbeda nyata dengan berat buah per tanaman yang dua bunganya dipangkas. Pemangkasan tunas juga berpengaruh nyata terhadap berat buah per tanaman dimana buah setiap tanaman yang satu tunasnya dipangkas paling berat dan berbeda nyata dengan berat buah setiap tanaman yang dua tunasnya dipangkas maupun berat buah per tanaman yang tiga tunasnya dipangkas.

Tabel 8. Berat Buah Per Tanaman (g)

\begin{tabular}{ccccc}
\hline Pemangkasan & \multicolumn{2}{c}{ Pemangkasan Tunas Lateral } & \multirow{2}{*}{ Rerata } \\
\cline { 2 - 4 } Bunga & 1 Tunas & 2 Tunas & 3 Tunas & \\
\hline 1 Bunga & $795,8 \mathrm{a}$ & $531,8 \mathrm{bc}$ & $471,7 \mathrm{bc}$ & $599,8 \mathrm{a}$ \\
2 Bunga & $576,7 \mathrm{~b}$ & $556,4 \mathrm{bc}$ & $553,7 \mathrm{bc}$ & $562,2 \mathrm{a}$ \\
3 Bunga & $471,3 \mathrm{bc}$ & $448,2 \mathrm{bc}$ & $427,7 \mathrm{c}$ & $449,1 \mathrm{~b}$ \\
\hline Rerata & $614,6 \mathrm{a}$ & $512,1 \mathrm{~b}$ & $484,4 \mathrm{~b}$ & $(+)$ \\
\hline Keterangan : & $\begin{array}{l}\text { Angka pada baris dan kolom yang diikuti dengan huruf yang sama } \\
\end{array}$ & tidak berbeda nyata menurut uji DMRT $\alpha 5 \% .(+):$ Terjadi interaksi \\
& antar faktor
\end{tabular}

\subsection{Jumlah Buah Per Petak}

Hasil sidik ragam (Anova) menunjukkan tidak terjadi interaksi antara pemangkasan tunas lateral dan bunga terhadap jumlah buah per petak.

Pemangkasan bunga tidak berpengaruh nyata terhadap jumlah buah per petak tetapi data Tabel 9. menunjukkan bahwa buah setiap petak yang satu bunga tanamannya dipangkas cenderung lebih banyak sedangkan buah setiap petak yang tiga bunga tanamannya dipangkas paling sedikit. Pemangkasan tunas berpengaruh nyata terhadap jumlah buah per petak dimana buah setiap petak dari tanaman yang tiga tunasnya dipangkas paling banyak dan berbeda nyata dengan jumlah buah per petak dari tanaman yang dua tunasnya dipangkas maupun yang satu tunasnya dipangkas.

\section{Tabel 9. Jumlah Buah Per Petak}

\begin{tabular}{|c|c|c|c|c|}
\hline \multirow{2}{*}{$\begin{array}{c}\text { Pemangkasan } \\
\text { Bunga }\end{array}$} & \multicolumn{3}{|c|}{ Pemangkasan Tunas Lateral } & \multirow{2}{*}{ Rerata } \\
\hline & 1 Tunas & 2 Tunas & 3 Tunas & \\
\hline 1 Bunga & 309524 & 333333 & 371032 & $337963 \mathrm{a}$ \\
\hline 2 Bunga & 267857 & 343254 & 376984 & $329365 \mathrm{a}$ \\
\hline 3 Bunga & 289683 & 281746 & 353175 & $308201 \mathrm{a}$ \\
\hline Rerata & $289021 \mathrm{c}$ & $319444 \mathrm{~b}$ & $367063 \mathrm{a}$ & $(-)$ \\
\hline Keterangan & $\begin{array}{l}\text { Angka pada ba } \\
\text { tidak berbeda } \\
\text { interaksi antar }\end{array}$ & $\begin{array}{l}\text { kolom ya } \\
\text { nenurut uj }\end{array}$ & $\begin{array}{l}\text { kuti dengan } 1 \\
\text { RT } \alpha 5 \% \text {. ( - }\end{array}$ & $\begin{array}{r}\text { yang sama } \\
\text { idak terjadi }\end{array}$ \\
\hline
\end{tabular}

\subsection{Berat Buah Per Petak}

Hasil sidik ragam (Anova) menunjukkan terjadi interaksi antara pemangkasan tunas lateral dan bunga terhadap berat buah per petak panen III dan total panen dimana berat buah setiap petak dengan tanaman yang satu tunas dan 
satu bunganya dipangkas paling berat dan berbeda nyata dengan berat buah setiap petak yang diberikan kombinasi perlakuan lainnya.

Tabel 10. Berat Buah Per Petak (t/ha)

\begin{tabular}{|c|c|c|c|c|c|}
\hline \multirow{2}{*}{ Waktu } & \multirow{2}{*}{$\begin{array}{c}\text { Pangkas } \\
\text { Bunga }\end{array}$} & \multicolumn{3}{|c|}{ Pemangkasan Tunas Lateral } & \multirow{2}{*}{ Rerata } \\
\hline & & 1 Tunas & 2 Tunas & 3 Tunas & \\
\hline \multirow{4}{*}{ Panen I } & 1 Bunga & 4,435 & 2,877 & 2,472 & $3,261 \mathrm{a}$ \\
\hline & 2 Bunga & 3,879 & 2,877 & 2,637 & $3,131 \mathrm{a}$ \\
\hline & 3 Bunga & 1,845 & 1,429 & 1,036 & $1,437 \mathrm{~b}$ \\
\hline & Rerata & $3,386 \mathrm{a}$ & $2,394 \mathrm{ab}$ & $2,048 \mathrm{~b}$ & $(-)$ \\
\hline \multirow{4}{*}{$\begin{array}{c}\text { Panen } \\
\text { II }\end{array}$} & 1 Bunga & 4,837 & 4,845 & 3,071 & $4,251 \mathrm{ab}$ \\
\hline & 2 Bunga & 4,403 & 5,240 & 5,038 & $4,894 \mathrm{a}$ \\
\hline & 3 Bunga & 3,518 & 3,679 & 4,073 & $3,757 \mathrm{~b}$ \\
\hline & Rerata & $4,253 \mathrm{a}$ & $4,588 \mathrm{a}$ & $4,061 \mathrm{a}$ & $(-)$ \\
\hline \multirow{4}{*}{$\begin{array}{l}\text { Panen } \\
\text { III }\end{array}$} & 1 Bunga & $9,992 \mathrm{a}$ & $5,067 \mathrm{~b}$ & $5,661 \mathrm{~b}$ & $6,907 \mathrm{a}$ \\
\hline & 2 Bunga & $4,881 \mathrm{~b}$ & $5,020 \mathrm{~b}$ & $5,397 b$ & $5,099 \mathrm{~b}$ \\
\hline & 3 Bunga & $5,190 \mathrm{~b}$ & $5,198 \mathrm{~b}$ & $4,992 \mathrm{~b}$ & $5,127 \mathrm{~b}$ \\
\hline & Rerata & $6,688 \mathrm{a}$ & $5,095 \mathrm{~b}$ & $5,350 \mathrm{~b}$ & $(+)$ \\
\hline \multirow{4}{*}{$\begin{array}{l}\text { Total } \\
\text { Panen }\end{array}$} & 1 Bunga & $19,264 \mathrm{a}$ & $12,790 \mathrm{~b}$ & $11,204 \mathrm{~b}$ & $14,419 \mathrm{a}$ \\
\hline & 2 Bunga & $13,163 b$ & $13,137 \mathrm{~b}$ & $13,071 \mathrm{~b}$ & $13,124 b$ \\
\hline & 3 Bunga & $10,554 \mathrm{~b}$ & $10,306 \mathrm{~b}$ & $10,101 \mathrm{~b}$ & $10,320 \mathrm{~b}$ \\
\hline & Rerata & $14,327 \mathrm{a}$ & $12,077 \mathrm{~b}$ & $11,459 \mathrm{~b}$ & $(+)$ \\
\hline
\end{tabular}

Pemangkasan tunal lateral berpengaruh nyata terhadap berat buah per petak total panen dimana buah setiap petak yang satu tunas lateralnya dipangkas paling berat dan berbeda nyata dengan pemangkasan dua atau tiga tunas lateral, demikian halnya dengan pemangkasan bunga juga berpengaruh nyata terhadap berat buah per petak total panen dimana buah setiap petak yang satu bunganya dipangkas paling berat dan berbeda nyata dengan pemangkasan dua atau tiga bunga.

\subsection{Berat Segar Berangkasan}

Hasil sidik ragam (Anova) menunjukkan terjadi interaksi antara pemangkasan tunas lateral dan bunga terhadap berat segar berangkasan dimana berangkasan segar tanaman yang tiga tunas dan satu bunganya dipangkas paling berat dan berbeda nyata dengan berat segar berangkasan tanaman yang tiga tunasnya dan tiga bunganya dipangkas serta berat segar berangkasan tanaman yang dua tunasnya dan tiga bunganya dipangkas tetapi tidak berbeda nyata dengan berat segar berangkasan tanaman yang diberikan kombinasi perlakuan lainnya.

Pemangkasan bunga berpengaruh nyata terhadap berat segar berangkasan dimana berangkasan segar tanaman yang satu bunganya dipangkas paling berat dan berbeda nyata dengan berat segar berangkasan tanaman yang tiga bunganya dipangkas tetapi tidak berbeda nyata dengan berat segar berangkasan tanaman yang dua bunganya dipangkas. Pemangkasan tunas tidak berpengaruh nyata terhadap berat segar berangkasan tetapi data Tabel 11. menunjukkan bahwa berangkasan segar tanaman yang satu tunasnya dipangkas cenderung lebih berat sedangkan berangkasan segar tanaman yang tiga tunasnya dipangkas paling ringan.

Tabel 11. Berat Segar Berangkasan (t/ha)

\begin{tabular}{ccccc}
\hline \multirow{2}{*}{ Pemangkasan } & \multicolumn{2}{c}{ Pemangkasan Tunas Lateral } & \multirow{2}{*}{ Rerata } \\
\cline { 2 - 4 } Bunga & 1 Tunas & 2 Tunas & 3 Tunas & \\
\hline 1 Bunga & $3,515 \mathrm{a}$ & $3,719 \mathrm{a}$ & $3,764 \mathrm{a}$ & $3,666 \mathrm{a}$ \\
2 Bunga & $3,401 \mathrm{a}$ & $3,673 \mathrm{a}$ & $3,401 \mathrm{a}$ & $3,492 \mathrm{a}$ \\
3 Bunga & $3,220 \mathrm{a}$ & $2,358 \mathrm{~b}$ & $2,132 \mathrm{~b}$ & $2,570 \mathrm{~b}$ \\
\hline Rerata & $3,379 \mathrm{a}$ & $3,250 \mathrm{a}$ & $3,099 \mathrm{a}$ & $(+)$ \\
\hline Keterangan : & $\begin{array}{l}\text { Angka pada baris dan kolom yang diikuti dengan huruf yang sama } \\
\end{array}$ & $\begin{array}{l}\text { tidak berbeda nyata menurut uji DMRT } \alpha 5 \% .(+) \text { : Terjadi interaksi } \\
\end{array}$ &
\end{tabular}

\subsection{Berat Kering Berangkasan}

Hasil sidik ragam (Anova) menunjukkan tidak terjadi interaksi antara pemangkasan tunas lateral dan bunga terhadap berat kering berangkasan.

Tabel 12. Berat Kering Berangkasan (t/ha)

\begin{tabular}{ccccc}
\hline Pemangkasan & \multicolumn{3}{c}{ Pemangkasan Tunas Lateral } & \multirow{2}{*}{ Rerata } \\
\cline { 2 - 4 } Bunga & 1 Tunas & 2 Tunas & 3 Tunas & \\
\hline 1 Bunga & 0,998 & 0,884 & 0,952 & $0,945 \mathrm{a}$ \\
2 Bunga & 0,816 & 0,930 & 0,998 & $0,915 \mathrm{a}$ \\
3 Bunga & 1,020 & 0,816 & 0,862 & $0,899 \mathrm{a}$ \\
\hline Rerata & $0,945 \mathrm{a}$ & $0,877 \mathrm{a}$ & $0,937 \mathrm{a}$ & $(-)$ \\
\hline Keterangan : & Angka pada baris dan kolom yang diikuti dengan huruf yang sama \\
& tidak berbeda nyata menurut uji DMRT $\alpha 5 \% .(-)$ : Tidak terjadi \\
& interaksi antar faktor
\end{tabular}

Pemangkasan bunga tidak berpengaruh nyata terhadap berat kering berangkasan tetapi data Tabel 12. menunjukkan bahwa berangkasan kering tanaman yang satu bunganya dipangkas cenderung lebih berat sedangkan berangkasan kering tanaman yang tiga bunganya dipangkas paling ringan.
Pemangkasan tunas juga tidak berpengaruh nyata terhadap berat kering berangkasan tetapi berangkasan kering tanaman yang satu tunasnya dipangkas cenderung lebih berat sedangkan berangkasan kering tanaman yang dua tunasnya dipangkas paling ringan.

\subsection{Indeks Panen}

Hasil sidik ragam (Anova) menunjukkan terjadi interaksi antara pemangkasan tunas lateral dan bunga terhadap indeks panen dimana indeks panen tanaman yang satu tunas dan satu bunganya dipangkas paling tinggi sedangkan indeks panen tanaman yang tiga tunas dan satu bunganya dipangkas paling rendah.

Pemangkasan bunga tidak berpengaruh nyata terhadap indeks panen tetapi data Tabel 13. menunjukkan bahwa indeks panen tanaman yang tiga bunganya dipangkas cenderung lebih tinggi sedangkan indeks panen tanaman yang dua bunganya dipangkas paling rendah. Pemangkasan tunas juga tidak berpengaruh nyata terhadap indeks panen tetapi indeks panen tanaman yang satu tunasnya dipangkas cenderung lebih tinggi sedangkan indeks panen tanaman yang tiga tunasnya dipangkas paling rendah.

Tabel 13. Indeks Panen (\%)

\begin{tabular}{ccccc}
\hline Pemangkasan & \multicolumn{3}{c}{ Pemangkasan Tunas Lateral } & \multirow{2}{*}{ Rerata } \\
\cline { 2 - 4 } Bunga & 1 Tunas & 2 Tunas & 3 Tunas & \\
\hline 1 Bunga & $84,5 \mathrm{a}$ & $77,4 \mathrm{bc}$ & $74,7 \mathrm{c}$ & $78,9 \mathrm{a}$ \\
2 Bunga & $79,4 \mathrm{abc}$ & $77,9 \mathrm{bc}$ & $75,7 \mathrm{bc}$ & $77,7 \mathrm{a}$ \\
3 Bunga & $76,9 \mathrm{bc}$ & $81,3 \mathrm{ab}$ & $78,9 \mathrm{abc}$ & $79,0 \mathrm{a}$ \\
\hline Rerata & $80,3 \mathrm{a}$ & $78,9 \mathrm{a}$ & $76,4 \mathrm{a}$ & $(+)$ \\
\hline Keterangan : & Angka pada baris dan kolom yang diikuti dengan huruf yang sama \\
& tidak berbeda nyata menurut uji DMRT $05 \% .(+)$ : Terjadi interaksi \\
& antar faktor &
\end{tabular}

\subsection{Pembahasan}

Pemangkasan satu tunas lateral menghasilkan buah setiap petak yang paling berat dibandingkan pemangkasan dua atau tiga tunas lateral, walaupun dengan jumlah buat per petak maupun per tanaman yang paling sedikit. Hal ini karena buah yang dihasilkan paling panjang walaupun berdiameter paling kecil sehingga setiap buahnya lebih berat dan buah setiap tanaman juga lebih berat Pemangkasan satu tunas juga memberikan pertumbuhan vegetatif tanaman berupa tanaman yang paling tinggi dengan diameter batang yang paling besar, walaupun permukaan daunnya tidak terlalu luas tetapi berangkasan yang dihasilkan baik segar maupun kering paling berat dengan nilai indeks panen juga yang tertinggi.

Pemangkasan satu bunga juga menghasilkan buah yang paling panjang tetapi tidak terlalu besar jika dibandingkan dengan pemangkasan dua atau tiga bunga sehingga setiap buah yang dihasilkan tidak terlalu berat, walaupun demikian jumlah buah pada setiap tanaman paling banyak sehingga buah per tanaman menjadi paling berat. Jumlah buah per petak juga paling banyak sehingga setiap petak juga menghasilkan buah yang paling berat.

\section{Simpulan}

Interaksi antara pemangkasan tunas lateral dan pemangkasan bunga berpengaruh nyata terhadap diameter batang, diameter buah, berat per buah, berat buah per tanaman, berat buah per petak panen III dan total panen, berat segar berangkasan dan indeks panen. Pemangkasan satu tunas lateral memberikan hasil buah per petak yang lebih baik seberat 14,327 t/ha jika dibandingkan dengan pemangkasan dua atau tiga tunas lateral. Pemangkasan satu bunga memberikan hasil buah per petak yang lebih baik seberat 14,419 t/ha jika dibandingkan dengan pemangkasan dua atau tiga bunga. Pemangkasan satu tunas dan satu bunga yang dilakukan bersama menghasilkan buah setiap petak tertinggi yang mencapai 19,264 t/ha.

\section{Pustaka}

Adisarwanto, T dan Wudianto, R. 2002. Meningkatkan Hasil Panen Kedelai di Lahan Sawah - Kering - Pasang Surut. Penebar Swadaya. Jakarta.

Cahyono, B. 1996. Mensukseskan Tanaman Melon. Aneka Solo. Solo.

Gernawi, Y. 1996. Hasil Tanaman Melon (Cucumis melo, L) pada berbagai takaran pupuk NPK dan pemangkasan. Laporan Penelitian. Balai Penelitian Universitas Jambi. Jambi.

Gomez, K A dan Gomez A A. 1995. Prosedur Statistik untuk Penelitian Pertanian. Edisi ke 2. Jakarta: UI Press.

Liana Dwi Sri Hastuti. 2007. Terung-Tinjauan Langsung ke Beberapa Pasar di Kota Bogor. USU Repository.

Muhammad. N., W. Dewayanti, L. Hutagulung dan Soegito. 2000. Pengaruh

Tipe Rambatan dan Pemangkasan Terhadap Pertumbuhan dan Hasil Markisa. Jurnal Hortikultura Vol.10.Hal:101.

Pracaya. 2002. Bertanam Sayuran organik di kebun, Pot dan Polibag. Penebar Swadaya, Jakarta.

Soetasad, A. Adi. 2000. Budidaya Terung Lokal dan Terung Jepang. Penebar Swadaya. Jakarta.

Soetasad. A. A dan S. Muryanti. 2000. Budidaya Terung Lokal dan Terung Jepang. Penebar Swadaya. Jakarta.

Sumiati. 1987. Pengaruh Pemangkasan Batang terhadap Hasil dan Kualitas Tomat. Bul. Penel. Hort. 15(1):48-54. 
Sunaryono, Hendro. 1984. Kunci Bercocok Tanam Sayur-Sayuran Penting diIndonesia. Bogor: CV. Sinar Baru.

Susanto, S., Pribadi, E.M., 2004. Pengaruh Pemangkasan Cabang dan Penjarangan Bunga Jantan terhadap Pertumbuhan dan Produksi Gherkin dengan Budidaya Hidroponik. J. Agron. Indones. 32. 